\title{
Educational Leadership During Times of Armed Conflict: Thailand's Lessons for Somalia
}

\author{
Lleij Samuel Schwartz ${ }^{1, *} \&$ Saeed Aden ${ }^{2}$ \\ ${ }^{1}$ Institute for Language Education, Southern New Hampshire University, 2500 North River \\ Road, Manchester, New Hampshire 03106-1045, United States \\ ${ }^{2}$ Dept. of African and African-American Studies, Harvard University, Barker Center 245, 12 \\ Quincy Street, Cambridge, MA 02138-3879, United States \\ *Corresponding author: Institute for Language Education, Southern New Hampshire \\ University, 2500 North River Road, Manchester, New Hampshire 03106-1045, United States. \\ Tel: 1-617-496-0864. E-mail: harago@gmail.com
}

Received: July 18, 2017 Accepted: October 15, 2017 Published: November 15, 2017

doi:10.5296/ije.v9i4.11566 URL: https://doi.org/10.5296/ije.v9i4.11566

\begin{abstract}
In this theoretical paper, the authors present the results of a collaborative effort to construct a teaching case centered on the challenges of educational leadership in the context of regions affected by the Somali insurgency. Noting a paucity of research in educational leadership for institutions situated in conflict zones, the authors present findings from prior research on educational leadership conducted in the restive southern provinces of Thailand that have the potential to be successfully applied in the similar context of post-conflict Somalia. The authors posit that comparative social policy methodology might be successful in identifying common challenges educational leaders in conflict zones around the world face, and leadership strategies that address those challenges.
\end{abstract}

Keywords: Educational leadership, armed conflict, Somalia, Thailand 


\section{Introduction}

The origins of this theoretical paper lie in the discussions held during a research project the two authors engaged in while they were doctoral students in an educational leadership program; both authors had prior experience teaching in regions beset by conflict from armed insurgency. One author would go on to do his dissertation research in post-conflict Somalia (Aden, 2017); whereas, the other author completed his dissertation research in second language acquisition in which some participants hailed from post-conflict societies (Schwartz, 2016). From these discussions, as well as their research, several premises were developed. Firstly, there are commonalities in both the difficulties and opportunities in educational leadership in such a context. Secondly, an irony exists in the fact that while education is a key factor in resolving seemly intractable civil conflicts, the security of educational institutions are not often given priority by policy makers involved in counterinsurgency operations. Thirdly, there seems to be a paucity of scholarship devoted to comparative studies of educational leadership during times of civil conflict. These premises were applied in the construction of a teaching case study and its response. In this paper, the authors detail both the case study and its response to draw attention to the commonalities and differences in educational leadership in the contexts of Somalia and southern Thailand, which the authors hope will encourage further scholarship in such a mode.

\section{The Case}

As part of his doctoral coursework, Aden (2015) constructed a case that revolved around the leadership challenges faced by educators in the context of post-conflict Somalia. In 1992, Somalia was plunged into civil war when the various factions that ousted Mohamed Siyad Bare from power began to fight among themselves (Samatar, 1992). The effect of 24 years of civil war upon the Somali educational system was devastating; the entirety of Somalia's free public educational system and infrastructure were destroyed in the conflict, which had the consequence of leaving Somali children vulnerable to recruitment as child soldiers and to sexual exploitation (Abdi, 1998; Abdinoor, 2008; Cassanelli \& Abdikadir, 2007). Presently, Somalia has experienced enough stability that government was established with a democratically-elected president, and this government has gained recognition from the international community. However, an extremist Al-Shabaab insurgency is still active in some pockets of the country. Due to the destruction of Somalia's public educational system during the war, now the vast majority of Somali educational institutions are privately-run (Abdinoor, 2008). In the regions affected by the insurgency, there have been reports of insurgent groups co-opting schools for indoctrination through forcing a strict Islamist curriculum upon the students and faculty under threat of deadly force (Aden, 2017; O'Malley, 2010). In addition, schools have been targeted by both insurgents and government forces as a place for the recruitment of child soldiers (Aden, 2017; Moyi, 2012; O’Malley, 2010). In explaining why nonsectarian education is often targeted by extremist groups, such as Al-Shabaab and Al-Qaida, Aden (2017) argued that while the majority of Muslims have a tolerant and moderate view of the world, a minority are angered by Western cultural and 
political influence, as well as, injustices committed against their fellow Muslims. According to Aden (2017), for this minority, an answer is found by inculcating in society a strict interpretation of Islam where the wrongs committed against Muslims by non-Muslims must be confronted with violence, as such "radical groups no matter what region they are in, have identified education as the best way to grow their influence and recruit youth into jihad, making schools and education a target for these groups" (p. 108). In his case study, Aden (2015) asked how educational leaders could fulfill the educative mission of their organizations under such circumstances considering that so much of it rested out of the hands of Somali educational leaders.

\section{Response}

The response by Schwartz (2015) to the case outlined by Aden (2015) was delimited within the context of a director of a nonsectarian, private K-12 school. Schwartz (2015) argued that this context was appropriate in that as a consequence of the collapse of the Somali state during a period of more than 26 years of continuous internal conflict, the vast majority of Somali educational institutions are privately-run (Abdi, 1998; Abdinoor, 2008). Responding to the case through this lens had an added benefit of allowing cogent reference to previous research on educational leadership in Southern Thailand, a region which has also suffered from an almost six-decades long Islamic insurgency that has also targeted secular educational institutions for attack (Brooks, 2015; Liow, 2010; Maxcy, Sungtong, \& Nguyen, 2010; Nitjarunkul, Suntong, \& Placier, 2014; Othman \& Wanlabeh, 2012). Schwartz (2015) asserted that this was particularly important in that no research that directly addresses educational leadership in the Somali context could be found that could be applied to the case outlined by Aden (2015).

Schwartz (2015) identified several findings from previous research on educational leadership in the context of the conflict in Southern Thailand that were potentially applicable to the Somali context. The first was found in the work of Brooks (2015), who described how public school principals in southern Thailand built and sustained trust within the conflict-affected communities their institutions serve; using Tschannen-Moran's (2004/2013) "five facets of trust" (p. 40) as a conceptual framework, Brooks (2015) discovered that the principals in her study employed a strategy she termed as "pushing and pulling," (p. 240) to build goodwill between their schools and the communities they are situated in. Brooks (2015) used pushing to refer to actions that increased the visibility of teachers within the community; whereas, she used pulling to refer to attempts to draw the community into school activities. Schwartz (2015) argued that a pushing/pulling strategy was a good fit for Somali educational leaders in that Abdinoor (2008) had already documented the tradition of community involvement in the provision of education as a consequence of the collapse of the Somali government after the fall of the Barre regime (Abdi, 1998; Abdinoor, 2008; Aden, 2015; Carr-Hill, 2015; Moyi, 2012). In other words, Somali educational leaders have an advantage over their Thai peers in that due to the fact that the vast majority of Somali educational institutions are now private and community-supported, less work would need to be done to establish trust within the 
community as the institution is directly a product of it. However, it should be noted that as Somalia emerges from 26 years of civil war, it has become a challenge for the infant Somali government to license, accredit and oversee the vast array of private schools and university that almost replaced the state sponsored educational system that existed before the civil war (Aden, 2017).

Secondly, Schwartz (2015) pointed to the work of Nitjarunkul, Sutong, and Placier (2014) who examined the challenges 21 primary school educators faced when implementing educational reform in schools situated in Thailand's restive southern provinces. It was found that for educators in this region, armed conflict brought challenges concerning instructional management, feelings of fear and low morale, and concerns over the security of property and staff; furthermore, the educators reported that the conflict brought challenges in building trust both between school staff and between the schools and their communities (Nitjarunkul, Sutong, \& Placier, 2014). Certain leadership characteristics displayed by the principals of these schools that were identified by Nitjarunkul, Suntong, and Placier (2014) could be of use in a Somali context include: the use of patience to reinforce positive behavior, advocacy for child-centered and culturally sensitive instructional methods, and collaboration with regional stakeholders. Furthermore, Nitjarunkul, Suntong, and Placier (2014) argued that due to the complexities inherent in educational leadership and change within the context of armed conflict, educational leadership preparation in Thai schools of education needed to do more to prepare future educational leaders in managing the emotional and psychological toll the insurgency has had upon educators and communities located in southern Thailand. The authors suggest that Somali universities should also heed the advice of Nitjarunkul, Suntong, and Placier (2014) and provide preparation for the unique challenges of educational leadership in the context of armed conflict. Likewise, as Carr-Hill (2015) documented, the irrelevance of the curriculum of formal schools to the nomadic pastoralists who compose 65 percent of the Somali population could be addressed by following Nitjarunkul, Suntong, and Placier's (2014) advice to localize instructional methodology.

\section{Conclusion}

It is argued by the authors that comparative social policy (Clasen, 2004) has the potential to be an appropriate methodology in which the complex and multivariate phenomenon of educational leadership in post-conflict societies could be analyzed; in this mode, the authors argue that previous findings from studies on educational leadership conducted in educational institutions located in the south of Thailand have saliency to the current Somali situation.

Aden (2017), who conducted one year's research in Somalia, which was published as his dissertation entitled, The Role of Peace Education in Schools in Post-Conflict Somalia, revealed that currently, schools in post-conflict Somalia mostly lack the themes of peace education identified by Reardon and Cabezudo (2002), particularly in areas run by Al-Shabaab, an Al-Qaida affiliate in Somalia. Taken together, the findings of Brooks (2015) and Nitjarunkul, Suntong and Placier (2014) suggest that educational leaders in the Somali context could benefit from the lessons learned by their peers in southern Thailand who have 
to manage educational institutions in the context of an Islamist insurgency. Considering the tradition of community involvement in the provision of education in Somalia (Abdinoor, 2008), it can be expected that leadership practices that foster collaborative decision making by bringing together community stakeholders and school administrators, as can be found in a pushing/pulling paradigm (Brooks, 2015) would be especially effective. Furthermore, it can also be expected that by increasing community trust and relevance in the curriculum (Aden, 2017), enrollment by rural students would increase; this would have the benefit of providing these children an education free of extremist radicalization, which would, in turn, hopefully lessen the pool of disaffected youth from which insurgent groups in Somalia could recruit. Finally, by applying the recommendations of Brooks (2015) and Nitjarunkul, Suntong, and Placier (2014), the authors believe that trust building between school and community stakeholders might make increased resources available to Somali educational leaders that could be used to improve both the security of the school and the quality of the instruction within. The authors hope that this paper will encourage further comparative research in educational leadership in the context of armed conflict.

\section{References}

Abdi, A. A. (1998). Education in Somalia: History, destruction, and calls for reconstruction. Comparative Education, 34(3), 327-340. https://doi.org/10.1080/03050069828171

Abdinoor, A. (2008). Community assumes the role of state in education in stateless Somalia. International Education, (Spring), 43-61. Retrieved from http://cehhs.utk.edu/publications/IE/generalinfo.html

Aden, S. (2015). Somali schools: Hot bed of radicalization. Unpublished manuscript, Southern New Hampshire University, Manchester, NH.

Aden, S. (2017). The Role of Peace Education in Schools in Post- Conflict Somalia (Doctoral dissertation). Southern New Hampshire University, Manchester, N.H.

Brooks, M. C. (2015). School principals in Southern Thailand: Exploring trust with community leaders during conflict. Educational Management Administration \& Leadership, 43(3), 232-252. https://doi.org/10.1177/1741143213513191

Carr-Hill, R. (2015). Education of children of nomadic pastoralists in Somalia: Comparing attitudes and behaviour. International Journal of Educational Development, 40(2015), 166-173. https://doi.org/10.1016/j.ijedudev.2014.10.00

Cassanelli, L., \& Abdikadir, F. S. (2007). Somalia: Education in transition. Bildhaan: An International Journal of Somali Studies, 7, 91-125.

Clasen, J. (2004). Defining comparative social policy. In P. Kennett (Ed.), A handbook of comparative social policy (pp. 91-102). Northhampton, MA: Edward Elgar.

Liow, J. C. (2010). Religious education and reformist Islam in Thailand's southern border provinces: The roles of Haji Sulong Abdul Kadir and Ismail Lufti Japakiya. Journal of 
Islamic Studies, 21(1), 29-58. https://doi.org/10.1093/jis/etp026

Maxcy, B. D., Sungtong, E., \& Nguyen, T. S. (2010). Challenging school leadership in Thailand's southern border provinces. Educational Management Administration \& Leadership, 38(2), 164-183. https://doi.org/10.1177/1741143209356360

Moyi, P. (2012). Girl's schooling in war-torn Somalia. International Journal of Educational Research, 53(2012), 201-212. https://doi.org/10.1016/j.ijer.2012.03.010

Nitjarunkul, K., Suntong, E., \& Placier, P. (2014). Challenges of educators in the context of education reform and unrest: A study of southern border provinces in Thailand. Asian Social Science, 10(18), 232-240. https://doi.org/10.5539/ass.v10n18p232

O'Malley, B. (2010). Education under attack 2010 (Education Under Attack, Rep.). Retrieved from http://unesdoc.unesco.org/images/0018/001868/186809e.pdf

Othman, A., \& Wanlabeh, N. (2012). Teachers' perspectives on leadership practices and motivation in Islamic private schools, Southern Thailand. Asian Education and Development Studies, 1(3), 237-250. https://doi.org/10.1108/20463161211270464

Samatar, A. I. (1992). Social decay and public institutions: The road to reconstruction in Somalia. In M. Doornbos, L. Cliffe, A. G. M. Ahmed, \& J. Markakis (Eds.), Beyond Conflict in the Horn: Prospects for peace, recovery and development in Ethiopia, Somalia and the Sudan (pp. 231-236). The Hague, The Netherlands: Institute of Social Studies.

Schwartz, L. (2015). A response to Saeed Aden's "Somali schools: Hot bed of radicalization." Unpublished manuscript, Southern New Hampshire University, Manchester, NH.

Schwartz, L. (2016). The Language Learning Needs of Beginner-Level International Students Enrolled in Intensive English Programs Affiliated with American Institution of Higher Education: A Case Study (Doctoral dissertation). Retrieved from ProQuest. (10242621)

Tschannen-Moran, M. (2013). Becoming a trustworthy leader. In M. Grogan (Ed.), The Jossey-Bass reader on educational leadership (3rd ed., pp. 40-54). San Francisco, CA: Jossey-Bass. (Original work published 2004

\section{Copyright Disclaimer}

Copyright for this article is retained by the author(s), with first publication rights granted to the journal.

This is an open-access article distributed under the terms and conditions of the Creative Commons Attribution license (http://creativecommons.org/licenses/by/3.0/). 